\title{
Green Job Opportunities Through the Curriculum and Community Enterprise for Restoration Science in New York City
}

\author{
Lauren Birney ${ }^{1}$ \& Denise M. McNamara ${ }^{2}$ \\ ${ }^{1}$ Pace University, USA \\ ${ }^{2}$ The College of Staten Island, USA \\ Correspondence: Lauren Birney, School of Education, Pace University, USA. Tel: 1-212-346-1889x11889. \\ E-mail: lbirney@pace.edu
}

Received: July 19, 2021

Accepted: August 9, 2021

Online Published: August 10, 2021

doi:10.20849/jed.v5i2.920

URL: https://doi.org/10.20849/jed.v5i2.920

\begin{abstract}
This paper examines the current understanding of the green economy movement and the critical role that education plays in attracting a viable workforce for this relatively new crusade. By connecting youth with the importance of environmental concerns in their community, tangible opportunities for sustainable change are created. By giving human agency to some of the most marginalized populations in New York City, the opportunity to experience environmental challenges in the community in which they live exposes these students to a plethora of enriching and rewarding employment opportunities. By combining the stewardship of their environment with formal and informal education, the Curriculum and Community Enterprise for Restoration Science in New York City is presenting multiple pathways for employment and educational opportunities in the green economy.
\end{abstract}

Keywords: green economy, sustainability, environmental restoration, oyster restoration

\section{Introduction $-21^{\text {st }}$ Century Skills and Unknown Employment Opportunities of the Future}

As the end of 1999 rapidly approached, two global concerns were brewing. One predicted Y2K technology failure causing internet failure. Airplanes falling out from the sky and nuclear melt were the consequences if this prediction came true (Mitchell, 2009). Fortunately, this never came to fruition. The second prediction was more realistic and inevitable. The need for $21^{\text {st }}$ Century skills by the workforce to successfully navigate education and career choices in an ever-changing employment landscape was sounded. The question asked was, "How do we train our youth for jobs that currently do not exist and skills that are at the moment, merely predictions?"

The challenge was directed to the leaders in education. Education is the conduit providing the $21^{\text {st }}$ - century skills to arm the learners to meet their needs and the needs of future generations. (Care, Kim, Vista \& Anderson, 2018). The skills needed for any of the predicted employment opportunities include collaboration, critical thinking, communication, flexibility, and an understanding of social and environmental issues and their implication. The persistent call for $21^{\text {st }}$-century skill development includes learning and innovation skills derived from critical thinking (Trilling \& Fadel, 2009). By shifting the mindset of traditional skills, it can be seen that $21^{\text {st }}$ Century skills are those that are fluid and transferable. Addressing the challenges of the $21^{\text {st }}$ Century such as environmental conservation and sustainability, emerging employment opportunities began to take hold. Global citizenship emerged in an increasingly shared worldwide concern. As stated by Alison Anderson (2012), thinking critically, solving problems, collaborating, and managing risks and uncertainty are core competencies that are critical for employment in a green economy while living together peacefully in a sustainable society.

Since the onset of the new millennium, there has been a major shift in educational learning goals concentrated on global citizenship and sustainable development (United Nations Department of Economics and Social Affairs UNDESA, 2018). Societal needs dictate the demand for a more scientifically literate citizenry with the capacity to study issues, understand the role that individuals and communities can play in developing responses, and the ability to work effectively to include diverse voices in the decision-making and problem-solving. Focusing issues of sustainability and preparing citizenry for green jobs through education is a natural fit for addressing $21^{\text {st }}$ Century challenges (Griswold, 2013). 
The convergence of a workforce in need of $21^{\text {st }}$-century skills, combined with S.T.E.M. education initiatives, and the demand to reverse human impacts on ecological systems initiated the Billion Oyster Project - Curriculum and Community Enterprise for Restoration Science in New York City, henceforth referred to as BOP-CCERS. Through the five pillars which support the BOP - CCERS project and the ameliorations of the project, initial exposure to the possibility of green jobs is established with the students in New York City and possibly more importantly, with marginalized populations who otherwise would not have the exposure to an array of employment opportunities that exist right in their own urban communities. This study will show that the creation of a more inclusive, diverse "green" workforce is a possibility when underserved students have the chance to engage in restorative ecological projects that are societally impactful.

\section{Green Jobs and Education}

Green jobs, as defined by the Bureau of Labor Statistics (2012), involve either providing or producing goods and services that benefit the environment and conserve resources or make a production process more environmentally friendly. These jobs help to protect ecosystems and biodiversity, reduce the consumption of energy, raw materials, and water through high-efficiency strategies and minimize or prevent the formation of all waste and pollution (Sanai \& D'Amico, 2015) Green jobs have the potential to impact society by changing all of the aspects of our lives, but most importantly our behavior (Lange, 2009). Research has shown (Griswold, 2013) that green jobs can serve to advance the development of sustainable societies through workforce development, science, technology, engineering and mathematics (S.T.E.M.) education, and sustainability values. The synergy created by combining these elements supports a system for addressing economic, environmental, and societal concerns through the green industry. Besides, green jobs offer more opportunities and better pay than the national economy average as a whole (Moro, Roth well \& Asha, 2011)

The term sustainable development was coined in 1987 and refers to development that meets the needs of the present without compromising the ability of future generations to meet their needs (Caelian, Serbian \& Burgh Elea, 2015). This does not only mean the environmental, social, and economic needs but also human capital needs which include education and employment. Through goal-oriented education in sustainability, young people are more likely to seek out green employment, develop stronger ties to their community, a better appreciation for the natural world, and a heightened commitment to serving as active, contributing citizens (Sobel, 2005). The opportunity for our education system is to use content, concepts, and real-world phenomena to help students to develop critical skills and inspire them to pursue challenging career paths (Wagner \& Dintersmith, 2015).

An economy is considered green when it supports increased productivity and efficiency of natural resources, reduces pollution, improves environmental risk management, and invests in maintaining the stability of ecosystems (Poverty-Environment Partnership, 2012). Green jobs are those that provide a living wage and (1) reduce consumption of energy and raw materials, (2) limit greenhouse gas emissions, (3) minimize waste and pollution and (4) protect and restore ecosystems (Kozluk, et al., 2013). It has been postulated that nationwide investment in water infrastructure would create 1.9 million green jobs (Gordon, Hays, Pollack, Sanchez \& Walsh, 2011).

Sector-specific job training is one of the channels for enlisting individuals in the green job movement but is found to rely on external factors such as unemployment rates and national economy fluctuations (Leahey, 2001). Jobs that are seen as not fulfilling can foster low morale, high absenteeism, and low productivity (Kocakulah, Kelley, Mitchell \& Ruggieri, 2016). An alternative is to empower the employee with a sense of self-efficacy and personal growth by developing a vested interest in local and global environmental challenges. Self-efficacy has been found to relate positively to interest in an activity and soft skills are an important employment characteristic (Bandura \& Schunk, 1981). By its very nature, this type of career would have to be explored at an earlier stage than in the on-the-job training option. Youth participation in local environmental issues can lead to social development and positive social change in communities (Schusler, Krasny, Peters \& Decker, 2009). Increased personal growth and self-esteem have been linked to immersive outdoor educational programs (D'Amato \& Krasny, 2011). The degradation of the environment and global warming are challenges that are faced worldwide. Providing young adults with opportunities to work in the green economy can reverse the effects of environmental degradation and improve the socio-economic status of those entering the field. A green economy is mainly based on renewable energy, green construction, and architecture, waste management, sustainable transport, water, food, and agriculture (Llewellyn, Bronwyn, \& Golden, 2008).

\section{Degradation of the Environment}

"The combination of having reputably the best oysters in the world in what had become unarguably the greatest harbor in the world made New York City for an entire century "the world's oyster capital" (Kurlansky, 2004). However, the oyster beds of New York Harbor began to show signs of depletion as early as 1810. Population 
growth increased the growth of commerce, triggering the over-harvesting of the oyster. Differences in how species respond to physical conditions lead to changes in their relative abundance within an ecosystem as species decline or increase in abundance, colonize new locations, or leave places where conditions are no longer favorable (Poloczanska, et al, 2013). The population growth in New York City had a ripple effect on the oyster population in the harbor. Gradually oyster beds began to dwindle and with the contamination of the waters in the estuary, the oysters became too polluted to eat. A ban on harvesting oysters from New York Harbor was enacted when it was felt the oysters were too polluted for consumption. New York Harbor and its watershed areas continued to suffer from the expansion of the city and both its biotic and abiotic systems suffered through increased contamination and pollution. It was not until 1972 that the Clean Water Act was passed (EPA, 33 U.S.C. $\$ 1251$ et seq., 1972). Although the Federal Water Pollution Control Act was passed in 1948, the mandates on industrial pollution were limited. In 1972, the act was restructured and expanded, requiring industrial and municipal facilities to obtain permits limiting their direct discharges into surface waters in the United States. Gradually, there was a resurgence in the quality of the waters of New York Harbor but oyster restoration efforts were not introduced for several more decades.

Environmental restoration is a term that has been extensively used in the past few decades. The need for the restoration of the environment is in part a consequence of natural phenomena but to a greater extent, because of the actions of mankind. The degeneration of natural habitats and the destruction of natural resources have consequential effects on both the biotic and abiotic components of the world's ecosystems. Energy flows connect the biotic and abiotic components and the delicate balance of these dynamic and homeostatic systems, none more than the rapid expansion of the human population and the demands that are placed on the environment. By meeting, and most times exceeding our needs, we have exacerbated environmental degradation to its breaking point.

Unfortunately, the pollution of the waterways around New York City was not the only area affected by the adverse influence of human impact. Global degradation of water, air, and land was occurring at a rapid and unchecked pace. As noted by several historians, rapid population growth and imbalances in the distribution of population concerning natural resources increased environmental degradation and is particularly evident in the pollution in coastal areas, especially where urban populations grow rapidly and critical resources are depleted at an accelerated rate (Furtado, Belt, \& Jammi, 2000). Due to the very nature of coastal areas and their access to transportation and water, most metropolitan areas around the world are situated on the coasts of continents and support economic and cultural exchange. The boundary between the land and the ocean is home to the coastal environments. Coastal environmental systems play a vital role in human well-being and economic capital, providing resources and employment opportunities but in turn, they are also vulnerable to anthropogenic impacts (Sherbinin, Carr, Cassels, \& Jiang, 2007). Anthropogenic (influence of humans on natural world) factors emerge as the dominant driver of change, both as planned exploitation of coastal resources and as unforeseen side effects of human activities. The buffer area between permanent land and water, the coastal active zone hosts a wide range of precious marine bio-systems (Mentaschi, Vousdoukas, Pekel, Voukouvalas, \& Feyen, 2018). Coastal areas host key infrastructures, ecosystems, and about $40 \%$ of the world's global population (Martinez, et al, 2007).

In the United States, the environmental movement began to take shape in the 1960s and 1970s. The use of toxic chemicals in insecticides was brought to the forefront with marine biologist Rachel Carson's scathing expose, Silent Springs (1962). The book not only documented the misuse of chemical pesticides but called into question the role of the federal government and its environmentally altering decision-making. Other events such as the pollution of Lake Erie - so polluted that it caught fire in 1969, galvanized the need for laws to protect the environment and meaningful consequences for violations of these laws. The 1970s brought forth several monumental legislative acts intended to create a more sustainable environment. In 1970, the Clean Air Act became the basic legislative framework for the control of air pollution. This was quickly followed by the Clean Water Act of 1972, regulating water quality and monitoring the discharge of pollutants into the water. Today, legislation can be found on the local, national and international levels. In response, metropolitan cities such as New York City and Los Angeles have initiated large urban sustainability plans (National Academies of Sciences, Engineering \& Medicine, 2016).

\section{The Curriculum and Community Enterprise for New York Harbor Restoration}

Since indicators point to youth participation being the foundational block for green careers, education plays a significant role in fulfilling this sector of the economy. To develop an environmentally literate population, and to solve the increasingly complex environmental issues facing society, there is a need to increase students' access to environmental education field experiences and to connect these outdoor experiences to relevant curricula within the classroom (O'Neil, et al., 2020). Programs that begin in middle and secondary schools can expose students to 
career opportunities in the green economy at the foundational level. Angela Calabrese Barton (2012) cites the need for a place in science education with disengaged youth. She further emphasizes the importance of the community immersion model and a deep and critical connection to their community. An example of this educational opportunity that is woven into workforce development, STEM education, and sustainability is the Curriculum and Community Enterprise for New York Harbor Restoration. The Billion Oyster Project (BOP) is a citizen science restoration project that has been in existence in New York Harbor since 2008. It was inspired by the Chesapeake Bay Oyster Recovery Project which was successful in replanting approximately 6.7 billion oysters in the bay. BOP has its origins in the restoration activities started by the faculty and students at the Urban Assembly Harbor School located on Governors' Island in New York Harbor. The goal of the Billion Oyster Project is to restore 1 billion oysters to New York Harbor by the year 2035.

In August 2014, the National Science Foundation (Award \# DRL 1440869) awarded \$5,374,972.00 to the Curriculum and Community Enterprise for New York Harbor Restoration in New York City Public Schools Project (CCERS). This added more structure and several new components to the Billion Oyster Project by creating a model of curriculum and community enterprise within the New York City public school system. Middle school students attending New York City schools in underserved communities were selected to study the New York harbor and its impact on the community within the harbor and surrounding it. Historical, geological, and environmental impacts are explored with the intent of eliciting empathy for the restoration of the native oyster population while instilling motivation for stewardship of the harbor, heightened motivation in STEM disciplines, and a possible pipeline to future career paths. Students experience higher levels of engagement and take a deeper approach to learn when they can apply what they are studying to address a real-world problem (Lombardi, 2007).

To accomplish these goals, the BOP CCERS project engages students in the restoration of the native oyster (Crassostrea virginica) habitats in New York Harbor through the combination of field research and classroom investigations. The project is based on five separate but interconnected pillars:

(1) Teacher education curriculum - created by CCERS staff and content experts in the partnership

(2) Student learning curriculum - created by CCERS staff and classroom teachers and implemented in the NYC middle school classrooms

(3) Digital platform for resources - housing lessons, units, empirical data from the field stations, and research papers

(4) After-school STEM program - conducted through the joint efforts of Good Shepard Services, the New York Academy of Science, and the NYC Department of Education

(5) Public exhibits - at the Hudson River Project headquarters and the New York Aquarium

The project is based on partnerships with several stakeholders including Pace University, the New York City Department of Education, the Columbia University Lamont-Doherty Earth Observatory, the New York Academy of Sciences, the New York Harbor Foundation, Good Shepherd Services, and the Hudson River Project among others. The strength of many community-based partnerships (Minkler, Vásquez, Tajik, \& Petersen, 2008), is the ability of the partners to demonstrate a strong commitment to collaborate with all stakeholders as well as the other partners in the project.

Table 1. Timeline of the Major accomplishments of the project

\begin{tabular}{|c|c|}
\hline By August 2015 & By August 2018 \\
\hline 11.5 million oysters grown in New York Harbor & 25 million oysters grown in New York Harbor \\
\hline 1.05 acres of reef area restored & 2.5 acres of reefs restored \\
\hline $\begin{array}{l}\text { Approximately } 93,600 \text { pounds of oyster shell } \\
\text { recycled }\end{array}$ & $\begin{array}{l}\text { Approximately } 1 \text { million pounds of oyster shells } \\
\text { recycled }\end{array}$ \\
\hline $\begin{array}{l}\text { The oysters have filtered approximately } 10.9 \text { trillion } \\
\text { gallons of New York Harbor water }\end{array}$ & $\begin{array}{l}\text { The oysters have filtered approximately } 25 \text { trillion } \\
\text { gallons of New York Harbor water }\end{array}$ \\
\hline $\begin{array}{l}\text { The oyster filtration has removed approximately } \\
6.75 \text { million pounds of nitrogen }\end{array}$ & $\begin{array}{l}\text { The oyster filtration has removed approximately } 16 \\
\text { million pounds of nitrogen }\end{array}$ \\
\hline
\end{tabular}

The project has been in existence since 2014 and the major impacts of the project can be seen in Table 1. 
In February 2018, the National Science Foundation (Award\# DRL 759006) awarded an additional $\$ 2,000,000.00$ to the Curriculum and Community Enterprise for a Keystone Species in New York Harbor. In addition to the original model and its areas of implementation, the project is expanding its real-world, problem-based curriculum model to focus on practices that increase student motivations and capacities to pursue careers in fields of science, technology, engineering, or mathematics (STEM). Science for all is a moral and ethical imperative. It opens the door to high-paying professions and demystifies urban environmental issues (Calabrese Barton, 2002). It levels the playing field by giving all students an equal opportunity.

Continuing to focus on New York Harbor and oyster restoration, students and teachers in grades K-12 conduct field research in support of restoring native oyster habitats, and the project is implemented by a broad partnership of institutions and community resources, including Pace University, the New York City Department of Education, the Columbia University Lamont-Doherty Earth Observatory, the New York Academy of Sciences, the New York Harbor Foundation, the New York Aquarium, and others.

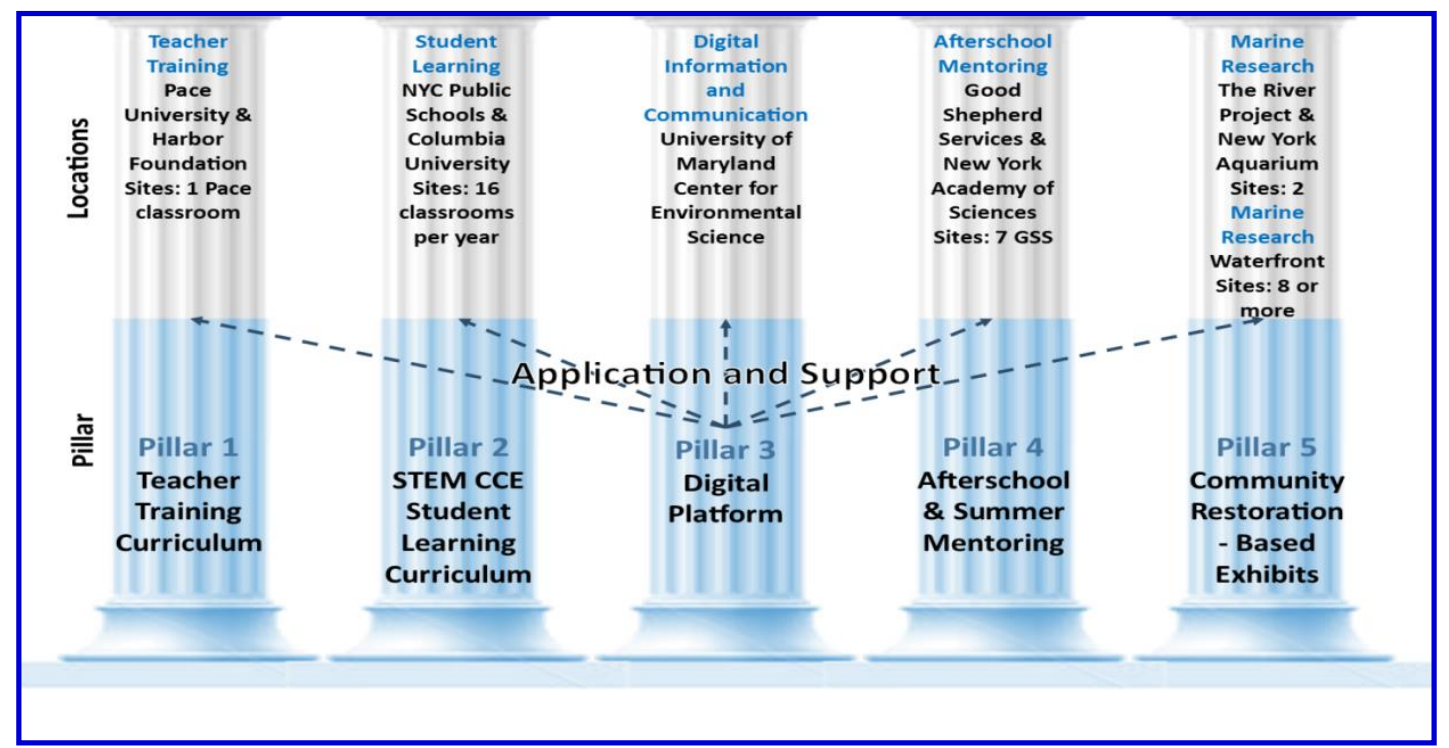

Figure 1. The Five Pillars of the STEM + Curriculum and Community Enterprise for Restoration Science

Each of the pillars in the project has been expanded to accurately depict the additions to the program.

The project model includes several interrelated components, including a teacher education curriculum that includes a component for elementary teachers that focuses on restoration science; a student learning curriculum; a digital platform for project resources; an aquarium exhibit; an after-school STEM mentoring program and a near-peer mentoring program; community-based restoration science hubs, and advanced methods in restoration science for high school students that include genetic barcoding (species ID), environmental DNA sampling and analysis, bacterial monitoring, and basic water chemistry analysis. The project targets students in low-income neighborhoods with high populations of English language learners and students from groups underrepresented in STEM fields and education pathways. The project directly involves 97 schools, over 300 teachers, and approximately 15,000 K-12 students over a period of four years. 


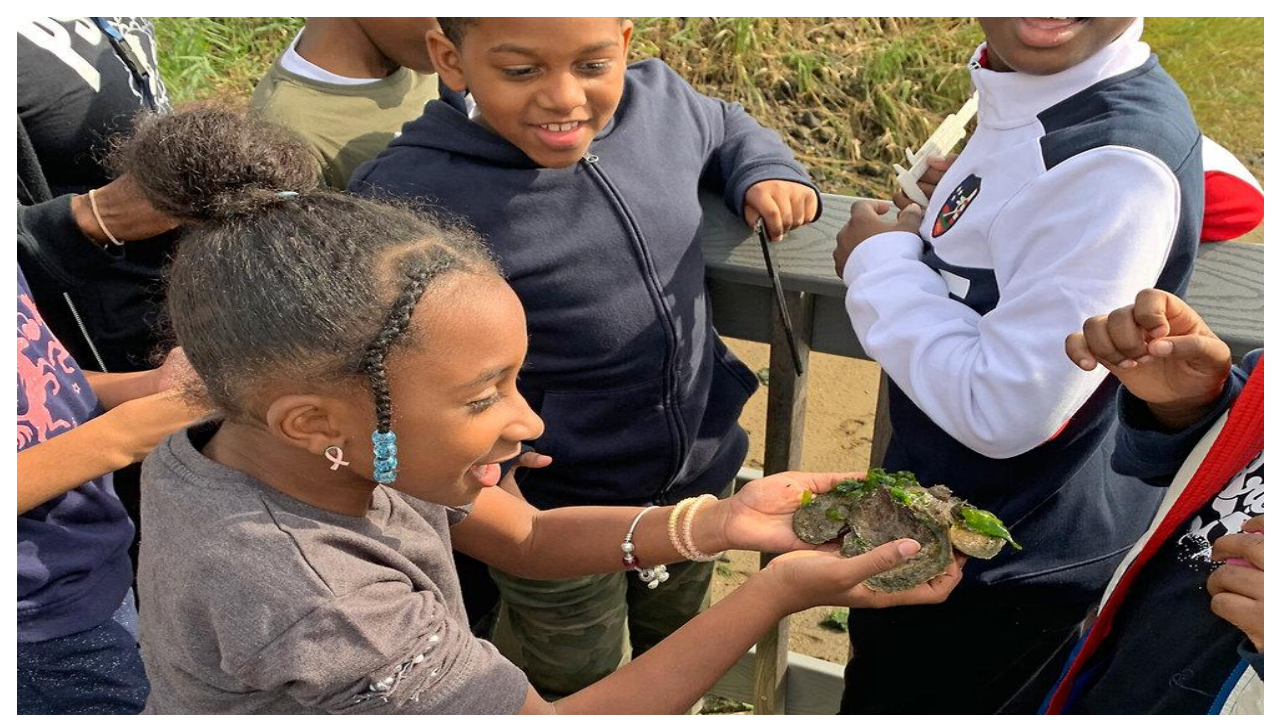

Figure 2. Oyster Research and Restoration in Canarsie, Brooklyn (2019)

\section{The Confluence of Green Careers and the Billion Oyster Project Curriculum and Community Enterprise for Restoration Science}

BOP-CCERS has become widely recognized and sought-after as a comprehensive STEM education program within the New York City Department of Education. Its fundamental goal has been to incorporate authentic environmental restoration science and inquiry-based research into the educational experience of students in predominantly low-income urban public schools. Of great significance in the pedagogical world is the fact that thousands of students who might otherwise have been lost in the complexities of the educational system in New York City are experiencing education through connections to community and nature In a study conducted on the impact of real-world learning and minority student achievement, (Cervantes, Hemmer \& Kouzekanani, 2015) researchers documented a statistically significant increase in the student achievement of low-income children when coupled with explicit support and high standards. As citizen science becomes more holistic, it embodies the responsibility of youths who are prepared to engage real concerns in their community (Mueller, Tippins \& Bryan, 2011). However, the enduring objective is focused on systemic outcomes that encourage and equip students to pursue practicable STEM career pathways. There is an urgent need to have the students understand the employment opportunities in a STEM-related career pathway. As reported in 2015, ninety-three of the 100 STEM occupations in the United States had wages above the national average (Fayer, Lacey \& Watson, 2017) and STEM occupations are growing at a much more robust level than non-STEM occupations.

The showcase for the connection between sustainable environmental education and green careers is the Urban Assembly New York Harbor School. The New York Harbor School is a secondary school in the New York City Department of Education and is unique in many ways. Located on Governors' Island in Lower New York Harbor, its 550 students can only reach their school by ferry. Once there, they are offered coursework that is found in no other school in New York City. The school's Career and Technology Education (CTE) offers seven programs of study, all focused on maritime content and skills, and each having practicing specialists acting as advisors and instructors. Research finds that high school CTE programs are associated with higher future employment and earnings (Jacobs, 2017). Each of the programs extends from the classroom to include a work-based learning component and provide a real-world context for practicing maritime skills. A section of the school's overview, found in the 2018-19 School Quality Snapshot (New York City Department Of Education, 2020) includes, "We work to develop authentic activities on, around and related to the water that creates a sense of responsibility to New York Harbor and develops a new generation of maritime advocates, enthusiasts, employees, and decision-makers". The seven programs offered at the Harbor Schools are:

1. Marine Policy \& Advocacy - this program is designed to guide students through the principles and applications of environmental/ marine policy and law by studying the Maritime industry and oyster restoration. Students develop a clear understanding of the Public Trust Doctrine, Clean Water Act, and other applicable statutes and regulations from state and City Marine \& Environmental Policy. Also, the students attend lobbying hearings related to the Albany and City legislature and visit with Pace University faculty in the Marine Policy Law Program. 
Utilizing analytics, web design, public speaking, writing, and developing critical thinking skills are developed and allow students to pursue college and begin to think about the fields of environmental education, environmental law, environmental journalism, environmental management, environmental ethics, environmental policy, urban planning and design, international environmental politics, and sustainable development management. The role of citizen involvement in policymaking on community, educational and governmental policy of water resources will be emphasized.

2. Marine Biology Research - students create Aquatic Ecosystem Models through three college-level courses, learning the basics of biology, ecology, oceanography, and statistics. The program consists of two paths - GIS geographic information system (map making) and Indy - Independent Marine Research (statistics). With the help of a scientist, these come together to create an environmental project and solution to a resource management issue for the Hudson-Raritan Estuary. In the Graphic Information System, students learn strong basic and intermediate skills in map-making. These skills are then applied to real-world projects as the student works in the Indy program. The Indy students acquire college-level reading, writing, and statistics and apply this to the real-world model. A scientist-mentor helps in the completion of the research using the student data to propose resource management solutions for the Hudson- Raritan Estuary. Included throughout the program are the management of projects, submission of professional reports, and presentations at national and international conferences. Finally, the focus is placed on career development through career exploration techniques, resume writing, and ePortfolio development.

3. Aquaculture - Aquaculture is an industry that is continually growing in response to the anthropogenic impact on the environment. Due to the growth of the human population and overfishing, the aquaculture industry has been expanding, both locally and globally. This program allows students to understand the rudiments of marine biology, environmental science, water chemistry, and animal husbandry through real-world projects. In concert with the Billion Oyster Project, students actively participate in the oyster restoration efforts by preparing the oysters for rebuilding. Students learn nutrient balance, water quality, feed ratios, filtration, system design, hydrology, fish disease identification and treatment, and entrepreneurship by designing recirculating aquaculture systems. Research projects, fieldwork, laboratory activities, classwork, internships, and work-based learning activities are all included to prepare the students for college and the workforce.

4. Ocean Engineers - This program is designed to expose students to the areas of engineering and technology. Using three-dimension modeling programs, students are tasked with designing, building, testing, and making alterations to remote underwater vehicles. These vehicles will be used to probe the harbor and are equipped with cameras and lights, making it possible to study the marine life. Attaining certification in Solidworks, the students now have the opportunity to apply this knowledge to the maritime industry or to further pursue marine engineering and technology in college. This program is unique to the Harbor School.

5. Professional Diving - students in this program have the opportunity to participate in the only such program in the country. The location of the Harbor school is the ideal setting for this diving program which allows the students to do underwater research connected to the CCERS Billion Oyster Project. Certification in entry-level open water diving and advanced open water diving prepare the students for both commercial and recreational work in the diving industry. The students also receive a foundation in scientific diving which can be applied if they decide to study marine science after high school. Among the skills learned are CPR and first aid, care for marine life injuries, emergency oxygen treatment, and rescue diving techniques. The knowledge and use of diving equipment such as dry suits, full face masks, harnesses, and tethers as well as underwater video and camera equipment are all part of this unique program. Career and Financial Management training is given to the students so that they can either work in recreational diving upon graduation or intern in professional diving opportunities like those offered at the New York Aquarium.

6. Vessel Operations - The focus of this program is geared toward commercial vessels and small passenger vessels. Students receive training in boat handling, navigation, safety at sea, and seamanship. This training prepares the students to become deckhands with the opportunity to advance their career to higher level maritime operations and management positions. The Harbor School's vessels serve as the training ground for this program and the students have firsthand experience as they practice mooring, overboard drills, and fire drills on ships such as the Indy 7 (originally part of the navy's fleet during the Vietnam War).

7. Marine Systems Technology - A vital part of the maritime industry is engineering. Marine technicians and welders, marine mechanics, and marine engineers all make a vital contribution to the maritime industry. Students in this program are trained both on board vessels and in shore-side marinas and shipyards. Areas of study include marine electrical systems and marine mechanics. The students work with wood, fiberglass/composite, and 
welding metal fabrications. Also, students can earn college-level courses through the Kingsborough Community College Maritime Technology program. Each of these fields of expertise (marine engineers, marine mechanics, marine technicians, and welders/metal fabricators) is in high demand offering competitive salaries with room for growth and advancement.

The student population of the Harbor School is $67 \%$ male and $33 \%$ female. Over $40 \%$ of the population is Hispanic, $25 \%$ of the population is categorized as Special Education students, and the school is entitled to Title I Funding. According to the 2018-2019 Quality Review for the Harbor School, "Strengths of the school include the integration of the instructional shifts into the CTE curricula to incorporate literacy, technology, scientific research, and real-world applications that offer college and career readiness. Additionally, the school effectively uses partnerships with The Harbor Foundation, industry partners, and university partners to support the school's mission of preparing students for college and careers" (New York City Department of Education, 2020). The data for students enrolled in the Certified Industry Programs is as follows:

Table 2. NYSED - 2017-2018 CTE Programs -Urban Assembly Harbor School (02M551)

\begin{tabular}{llll}
\hline Program & Program Industry Cluster & $\begin{array}{l}\text { NYSED } \\
\text { Approved }\end{array}$ & $\begin{array}{l}\text { Student } \\
\text { Count }\end{array}$ \\
\hline Diver, Professional, and Instructor & $\begin{array}{l}\text { Transportation, Distribution \& } \\
\text { Logistics }\end{array}$ & YES & 63 \\
Marine Science/Merchant Marine Officer & $\begin{array}{l}\text { Transportation, Distribution, and } \\
\text { Logistics }\end{array}$ & YES & 63 \\
Water, Wetlands, and Marine Resources & $\begin{array}{l}\text { Agriculture, Food and Natural } \\
\text { Management }\end{array}$ & YES & 65 \\
$\begin{array}{l}\text { Robotics Technology/Technician } \\
\text { Aquaculture }\end{array}$ & $\begin{array}{l}\text { Manufacturing Production } \\
\text { Agriculture, Food and Natural }\end{array}$ & YES & 67 \\
$\begin{array}{l}\text { Marine Maintenance/Fitter and Ship Repair } \\
\text { Technology/Technician }\end{array}$ & $\begin{array}{l}\text { Resources } \\
\text { Transportation, Distribution, and } \\
\text { Logistics }\end{array}$ & YES & 72 \\
\hline
\end{tabular}

As shown in Table 2, the programs align with the industry clusters for approval by the New York State Education Department.

\section{COVID19 - Serendipitous Benefits of the COVID19 Pandemic}

In March 2020, COVID-19 had invaded New York City and its insidious effects were far-reaching. Businesses were converted to at-home, online operations, restaurants were closed or reimagined as take-out only facilities and all of the schools in New York City were shuttered. This turn of events abruptly halted the shell collection program at Billion Oyster Project. Additionally, this drastically decreasing the stewardship of New York Harbor and virtually placed maintenance of the Oyster Restoration Stations on hold. The waters of New York Harbor experienced a reduction in maritime activity and the impact on the aquaculture was palpable. The result was a serendipitous resurgence of vitality throughout the New York estuary. Samples of the collected water were clearer and less polluted, aquatic life was seen in areas of the harbor that had not had life for some time and people were even swimming in waters that were once deemed, "the most heavily polluted and physically degraded of any in the United States" (U.S. Department of Commerce, 1988). While these improvements in environmental pollution are considered to be temporary, the current level of pollution in the atmosphere, biosphere, and hydrosphere could be much lower than the pre-COVID-19 period (Yunus, Masago \& Hijioka, 2020). Although COVID-19 has had a temporarily positive effect on the environment, much of the progress of the oyster restoration must be done in person. Without the citizen science volunteers and the students to monitor the Oyster Restoration Stations and reintroduce new oyster reefs into the harbor, the fieldwork on the project came to a near stand-still. Shell collection has also suffered during the COVID-19 crisis as restaurants had to limit their capacity to outdoor and take out dining only. The shells are needed as the surface for the oyster spat to adhere to and grow.

With the help of the New York State Environmental Protection Agency, the fieldwork began again in July 2020. Millions of oysters that were fastened to the recycled shells were barged up the East River and placed in the 
waters of the Soundview Park - the intersection of the Bronx and East Rivers. As stated by Pete Malinowski, Executive Director of Billion Oyster Project, "Years of work-conducting research, collecting shells, and designing reef structures - have all led up to a four- to six-week installation window this summer. I am grateful to the Billion Oyster Project team and our dedicated project partners who, despite setbacks associated with COVID-19, managed to keep this restoration effort on track" (Simko, 2020). In direct response to the pandemic, socially distanced "quaran-teams" were able to install an estimated 40 million oyster during the summer of 2020. Remote schooling was the primary form of education in New York City and in response, the staff at the BOP+CCERS Project created over 500 hours of educational videos to continue a seamless educational experience for the students.

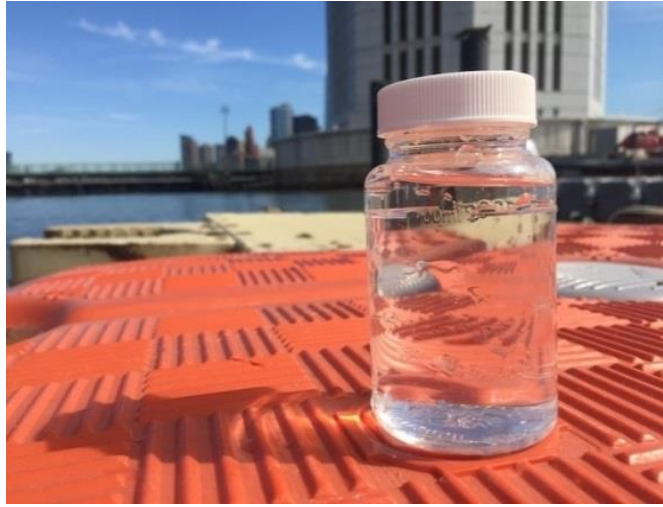

Figure 3. Water Sample from

the mouth of the East River (6-26-20)

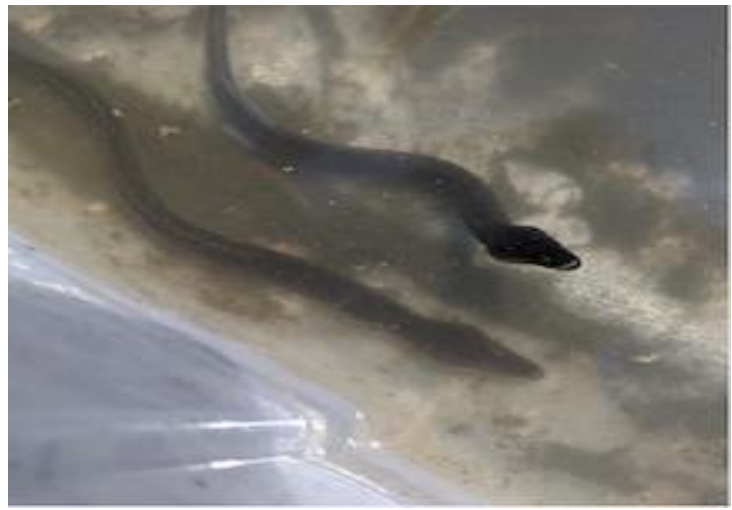

Figure 4. American Eels

in the Gowanus Canal (8-7-20)

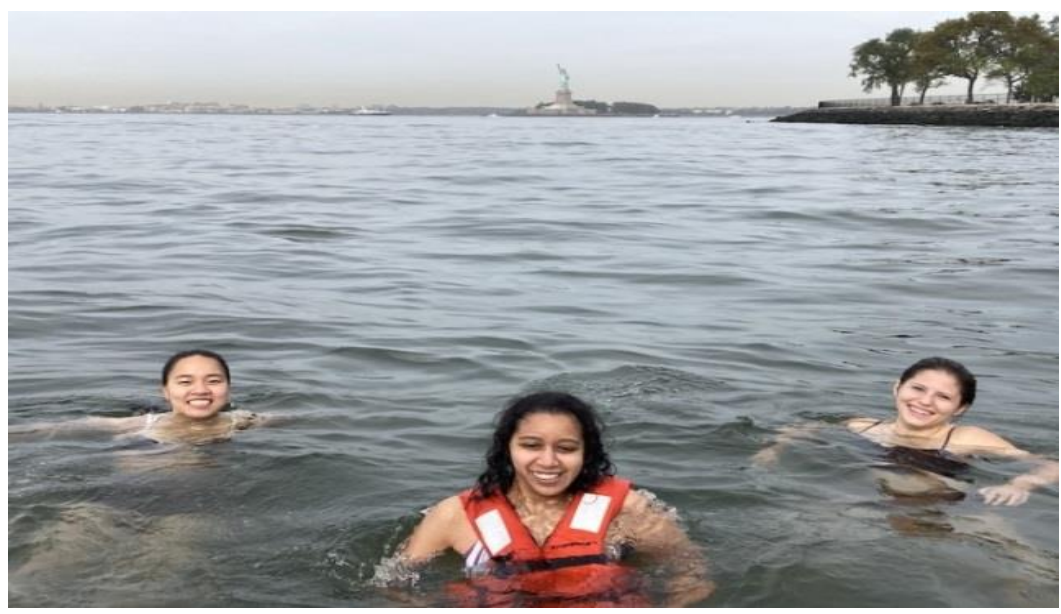

Figure 5. Citizen scientists in the waters of New York Harbor

\section{Implications for Expansion of the Project}

The findings garnered by the external evaluation team for the BOP-CCERS Project indicate that participating students reported knowing more about careers in marine, enginerering and environmental sciences than students in the comparision group. Participating students responded 0.73 points more positively than the student comparision group. In an unpaired t-test between the groups, the results were statistically significant. In addition, it was reported that participating in the project does increase student knowledge about STEM careers and improves their perceptions of their scientific skills compared to those with less involvement in the project.

Most of the over 6,000 students who participate in the BOP-CCERS Project are from both high poverty communities and are representative of underserved populations who are underrepesesented in STEM coursework 
and by extension, STEM Careers. The Curriculum and Community Enterprise for Restoration Science and its many iterations, can be found in over $100 \mathrm{~K}-12$ school in New York City. The alternative career exploration, with its focus on the restoration of the New York City Harbor's waterways, and the natives species found within, especially the oyster restoration, opens possibilities to thousands of students who would overwise have not been exposed to this potential field. Being able to initiate the STEM pipeline early in a student's education path and continue this through all grades and into post secondary education allows for a better opportunity for career choices in the green economy.

The potential implications drawn from the success of this project can have universal appeal and application, much like the other oyster restoration projects that are going on throughout the country (e.g., Charlotte Harbor Estuary, Punta Gorda, Florida; Oyster Recovery Partnership, Chesapeake Bay, Maryland; Olympia Oyster Restoration, Fidalgo Bay, Washington). Each of these restoration efforts is supported through the communities in which they are situated and relies on the partnerships they have established. What makes the Curriculum and Community Partnership for Restoration Science unique is the inclusion of the New York City Department of Education as one of its lead partners. These students are benefiting from a socially and environmentally significant learning experience. Its replication in other locations could have a substantial impact on other communities as well.

Building on the practical applications seen in this study and others with similar goals, and the recent developments in the Biden Administration's focus on Global Warming and Greenhuose Gas Reduction seem to indicate that green education and employment opportunities will continue along their current trajectory.

\section{Conclusion}

Before the last 25 million oysters were placed in the waters of Soundview Park, 30 million oysters had already been restored to New York Harbor and the surrounding waters that compose its estuary, 13 reefs have been installed across the five boroughs and 15 million shells from 75 donating restaurants had been collected. Pre-COVID-19, over 6,000 NYC students from more than 100 schools had been participating in the project. This is the biggest shellfish installation in the history of New York and it is poised to being the answer to protecting the city from storm surge while keeping the waterways clean.

After the devastation of Super Storm Sandy in 2012, funding from the U.S. Department of Housing and Urban Development and the State of New York was implemented for the Staten Island Living Breakwater Project. The purpose of the project is three-fold:

1. Curb Environmental Degradation - To reduce or prevent shoreline erosion, both short and long-term aimed at preventing damage to building and infrastructure.

2. Habitat Enhancement - To increase the fauna, flora, and aquatic habitats in the harbor and simulate the rocky structure of the acres of oyster reefs that once were found in the area.

3. Human Capital - To build community through pedagogy, ecosystem stewardship, scientific research, and citizen science activities and enhance the green economy.

At the forefront of the Living Breakwater Project is the inclusion of the CCERS + BOP Project. Active oyster restoration on and adjacent to the breakwaters will further enhance the habitat opportunities created by the breakwaters. The oyster wirework containers will use the same design being employed by the Billion Oyster Project in locations in the Harbor as part of the Hudson Raritan Estuary comprehensive restoration plan (GOSR, 2020). Also, a proposal for a Climate Center on Governors' Island, offering public programs, offices for green technology companies, and a research institute is on the slate for review by City Hall (Kimmelman, 2020).

The CCERS + BOP Project and the CTE coursework strands are the essential conduits for connecting New York City students to their marine environment. Facilitating early access to the scientific community is important for encouraging participation in science, technology, engineering, and mathematics (STEM) research careers and fostering persistence in that career pathway. For STEM engagement in higher education and the workforce to succeed, youth need exposure to role models and connections with mentors who can show them that a STEM career path is attainable (Garces \& Espinosa, 2013). One of the major tasks of high school students is to plan and make career decisions regarding post-secondary career options (Mei, Wei, \& Newmeyer, 2008). To make such decisions, students are required to have an understanding of the career opportunities that are available to them early enough to engage in proactive secondary school course options. Nowhere is that more evident than in the Career and Technical Education options. The Urban Advantage Harbor School has combined the CTE and CCERS + BOP to fill a void that is unique to New York Harbor and its estuaries but can also serve as a model for any school system that is located in or near a major harbor. No swath of the economy has been more widely 
celebrated as a source of economic renewal and potential job creation than the green economy (Muro, Rothwell \& Saha, 2011). With employment levels, that range from lower-skilled worked to high-end innovative careers, and the benefits to human capital and environmental improvement, the green economy seems to hold the most promise for social and economic betterment. Models such as the CCERS + BOP are the key to obtaining the workforce needed to make this promise a reality. Shellfish restoration can transform, through education and hands-on participation in rebuilding nature, how local communities value and perceive the ecological landscape in their backyards (DeAngelis et al., 2018).

\section{References}

Aceleanu, M. I., Serban, A. C., \& Burghelea, C. (2015). Greening the Youth Employment - A Chance for Sustainable Development. Sustainability, 7, 2623-2643. https://doi.org/103390/su7032623

Anderson, A. (2012). Unsustainable Development: The Missing Discussion about Education at Rio+20. Center for Universal Education at Brookings, Washington, D.C. Retrieved from https://www.brookings.edu/research/unsustainable-development-the-missing-discussion-about-education-atrio $20 /$

Asnawi, R., \& Djatmiko, I. W. (2015). A Challenge of Vocational Education for Preparing Green Employment [Conference Presentation]. The $3^{\text {rd }}$ UPI International Conference on Technology and Vocational Education Training (TVET), pp. 175-178. https://doi.org/10.2991/ictvet-14.2015.39

Bandura, A., \& Schunk, D. H. (1981). Cultivating competence, self-efficacy and intrinsic interest through proximal self-motivation. Journal of Personal and Social Psychology, 41, 586-598. https://doi.org/10.1037/0022-3514.41.3.586

Bureau of Labor Statistics. (2012). Measuring green jobs. Retrieved from http://www.bls.gov/green/

Calabrese Barton, A. (2002). A Commitment to Equity, Social Justice and a Sense of Place. Studies in Science Education, 38, 1-38 https://doi.org/10.1080/03057260208560186

Calabrese Barton, A. M. (2012). Citizen(s') Science. A Response to "The Future of Citizen Science". Democracy \& Education, 20(2), Article 12. Retrieved from https://democracyeducationjournal.org/home/vol20/iss2/12

Care, E., Kim, H., Vista, A., \& Anderson, K. (2018). Education system alignment for 21st Century Skills. Center for Universal Education at Brookings, Washington, D.C. Retrieved from https://www.brookings.edu/wp-content/uploads/2018/11/Education-system-alignment-for-21st-century-skill s-012819.pdf

Carson, R. (1962). Silent Springs. New York, NY: Houghton Mifflin Company.

Cervantes, B., Hemmer, L., \& Kouzekanani, K. (2015). The impact of project-based learning on minority student achievement: Implications for school redesign. NCPEA Education Leadership Review of Doctoral Research, 50 .

D'Amato, L. G., \& Krasny, M. E. (2011). Outdoor adventure education: Applying transformative learning theory to understanding instrumental learning and personal growth in environmental education. The Journal of Environmental Education, 42(2), 237-254.

DeAngelis, B., Birch, A., Malinowski, P., Abel, S., DeQuattro, J., Peabody, B., \& Dinnel, P. (2019). A Variety of Approaches for Incorporating Community Outreach and Education in Oyster Reef Restoration Projects: Examples from the United States. In Smaal, A., Ferreira, J., Grant, J., Petersen, J., \& Strand, Ø. (Eds.), Goods and Services of Marine Bivalves. Springer, Cham. https://doi.org/10.1007/978-3-319-96776-9_18

Environmental Protection Agency. (1972). Summary of the Clean Water Act. USEPA, Washington, D.C. Retrieved from https://www.epa.gov/laws-regulations/summary-clean-water-act

Environmental Protection Agency. (2019). Protecting the Marine Environment. USEPA, Washington, D.C. Retrieved from https://www.epa.gov/international-cooperation/protecting-marine-environment

Fayer, S., Lacey, A., \& Watson, A. (2017). STEM occupations: Past, present, and future. Retrieved from https://www.bls.gov

Furtado, J. I., Belt, T., \& Jammi, T. (2000). Economic development and environmental sustainability: policies and principles for a durable equilibrium. Washington, DC: World Bank Institute.

Garces, L. M., \& Espinosa, L. L. (2013). Promoting access to undergraduate STEM education: The legal and policy environment. The Bridge, 43(1), 34-42. Retrieved from https://www.nae.edu/File.aspx?id=70996 
Gordon, E., Hays, J., Pollack, E., Sanchez, D., \& Walsh, J. (2011). Waterworks: rebuilding infrastructure, creating jobs. In greening the environment. Retrieved February 12, 2020, from https://pacinst.org/publication/upgrading-water-systems-can-reduce-pollution-and-put-1-9-million-people-t o-work/

Governor's Office of Storm Recovery. (2020). Learn More about the Living Breakwaters. Retrieved from https://stormrecovery.ny.gov/learn-more-about-living-breakwaters-project

Griswold, W. (2013). Community Education and Green Jobs - Acknowledging Existing Connections. Adult Learning, 24(1), 30-36. https://doi.org/10.1177/1045159512467322

Jacob, B. A. (2017). What we know about Career and Technical Education in high school. Center for Universal Education at Brookings, Washington, D.C.. Retrieved from https://www.brookings.edu/research/what-we-know-about-career-and-technical-education-in-high-school/

Kimmelman, M. (2020). A Climate Center on Governors' Island? Could be a game-changer. New York Times, September $17,2020 . \quad$ Retrieved from https://gov-island-site.s3.amazonaws.com/press/TGI-Climate-Center-Release.pdf?mtime=20200916120727

Kocakulah, M. C., Kelley, A. G., Mitchell, K. M., \& Ruggieri, M. P. (2016). Absenteeism Problems and Cost: Causes, Effects and Cures. International Business and Economics Research Journal, 15(3), 89-96. https://doi.org/10.19030/iber.v15i3.9673

Kozluk, T., Zarnic, Z., Kim, H., Sheng, F., Bassi, A., Lehmann, M., ... Lange, G. (2013). Moving towards a Common Approach on Green Growth Indicators. [Conference Presentation] 2nd Annual GGKP Conference, April 4-5, 2013 in Paris, France. Retrieved from http://www.greengrowthknowledge.org/resource/moving-towards-common-approach-green-growth-indicators

Kurlansky, M. (2006). The Big Oyster: History on the Half Shell. New York, NY: Random House, Inc.

Lange, E. A. (2009). Fostering Learning sanctuary for transformation in sustainability education. In J. Mezirow, \& E. W. Taylor (Eds.), Transformative Learning in practice: Insights from community, workplace, and higher education (pp. 193-204). San Francisco, CA: Jossey-Bass.

Leahey, E. (2001). A help or a hindrance? The impact of job training on the employment status of disadvantaged women. Evaluation Review, 25(1), 29-54. https://doi.org/10.1177/0193841X0102500102

Llewellyn, A., Bronwyn, J. P., Hendrix, \& Golden, K. C. (2008). Green Jobs: A Guide to Eco-friendly Employment. Avon, Mass., Adams Media.

Lombardi, M. (2007). Authentic learning for the 21st Century: an overview. Educause Learning Initiative, ELI Paper 1/:2007. Retrieved from http://net.educause.edu/ir/library/pdf/ELI3009.pdf

Martinez, M. L., Intralawan, A., Vazquez, G., Perez-Maqueo, O., Sutton, P., \& Landgrave, R. (2007). The coasts of our world: ecological, economic and social importance. Ecological Economics, 63(2-3), 254-27. https://doi.org/10.1016/j.ecolecon.2006.10.022

Mei, T., Wei, P., \& Newmeyer, M. (2008) Factors influencing high school students career aspirations. Professional School Counseling, 11(5), 285-295. https://doi.org/10.1177/2156759X0801100502

Mentaschi, L., Vousdoukas, M. I., Pekel, J. F., Voukouvalas, E., \& Feyen, L. (2018). Global long-term observations of coastal erosion and accretion. Scientific Reports, 8(1), 12876. https://doi.org/10.1038/s41598-018-30904-w

Minkler, M., Vásquez, V. B., Tajik, M., \& Petersen, D. (2008). Promoting environmental justice through community-based participatory research: The Role of community and partnership capacity. Health Education \& Behavior, 35, 119-138. https://doi.org/10.1177/1090198106287692

Mueller, M. P., Tippins, D., \& Bryan, L. A. (2011). The Future of Citizen Science. Democracy \& Education, 20(1), 1-12. Retrieved from https://democracyeducationjournal.org/home/vol20/iss1/2

Muro, M., Rothwell, J., \& Saha, D. (2011). Sizing the clean economy: a national and regional green jobs assessment. Center for Universal Education at Brookings, Washington, D.C. Retrieved from https://www.brookings.edu/wp-content/uploads/2016/06/0713_clean_economy.pdf

National Academies of Sciences, Engineering, and Medicine. (2016). Pathways to Urban Sustainability: Challenges and Opportunities for the United States. Washington, DC: The National Academies Press. https://doi.org/10.17226/23551 
New York City Department of Education. (2020). The Urban Assembly New York Harbor School 2018-2019 $\begin{array}{llll}\text { Comprehensive } & \text { Education } & \text { Plan. } & \text { from }\end{array}$ https://www.nycenet.edu/Documents/oaosi/cep/2018-19/CEP_M551.pdf

O'Neil, J. M., Newton, R. J., Bone, E. K., Birney, L. B., Green, A. E., Merrick, B., ... Fraioli, A. (2020). Using urban harbors for experiential, environmental literacy: Case studies of New York and the Chesapeake Bay. Regional Studies in Marine Science, 33(2020), 100886. https://doi.org/10.1016/j.rsma.2019.100886

Poloczanska, E. S., Brown, C. J., Sydeman, W. J., Kiessling, W., Schoeman, D. S., Moore, P. J., ... Richardson, A. J. (2013). Global Imprint on climate change on marine life. Nature Climate Change, 3, 919-925. https://doi.org/10.1038/nclimate1958

Poverty-Environment Partnership. (2012). Building an Inclusive Green Economy for All: Opportunities and Challenges for Overcoming Poverty and Inequality. World Resources Institute, Washington, DC. Retrieved from https://www.wri.org/publication/building-inclusive-green-economy-all

Schusler, T. M., Krasny, M. E., Peters, S. J., \& Decker, D. J. (2009). Developing citizens and communities through youth environmental action. Environmental Education Research, (15), 111-127. https://doi.org/10.1080/13504620802710581

Sherbinin, A. D., Carr, D., Cassels, S., \& Jiang, L. (2007). Population and Environment. Annual Review of Environment and Resources, 32, 345-373. https://doi.org/10.1146/annurev.energy.32.041306.100243

Simko, A. (2020). Twenty-five Million Baby Oysters Arrive in the Bronx. Waterfront Alliance. Retrieved from https://waterfrontalliance.org/2020/07/22/twenty-five-million-baby-oysters-arrive-in-the-bronx/

Sobel, D. (2005). Place-based education: Connecting classrooms and communities. Great Barrington, MA: The Orion Society.

Trilling, B., \& Fadel, C. (2009). 21st Century Skills: Learning for Life in Our Times. San Francisco, CA: John Wiley \& Sons.

United Nations Department of Economic and Social Affairs. (2018). The Sustainable Development Goals Report 2018. UN, New York. https://doi.org/10.18356/7d014b41-enn

United States Department of Commerce. (1988). Hudson/Raritan Estuary: Issues, Resources, and Management. NOAA Estuary-of-the-Month, Seminar Series No. 9. Retrieved from https://repository.linbrary.noaa.gov/wiew/noaa/2850/noaa_2850_DS1.pdf

Wagner, T., \& Dintersmith, T. (2015). Most Likely to Succeed: Preparing our Kids for the Innovation Era. New York, NY: Scribner Publishing.

Yunus, A. P., Masago, Y., \& Hijioka, Y. (2020, August). COVID-19 and surface water quality: Improved lake water quality during the lockdown. Science of the Total Environment, 731. https://doi.org/10.1016/j.scitotenv.2020.139012

\section{Copyrights}

Copyright for this article is retained by the author(s), with first publication rights granted to the journal.

This is an open-access article distributed under the terms and conditions of the Creative Commons Attribution license (http://creativecommons.org/licenses/by/4.0/). 